\title{
THE EFFECT OF EMOTIONAL MARKETING AND LIFESTYLE ON CUSTOMERS DECISIONS IN PRODUCTS CHOOSING OF MURABAHAH FINANCING AT PT BANK SYARIAH MANDIRI KC PALEMBANG SIMPANG PATAL
}

\author{
Cepaldo ${ }^{1)}$, Rika Lidyah ${ }^{2)}$, Ariyanti ${ }^{3)}$ \\ ${ }^{1,2,3,4)}$ The Faculty Of IslamicEconomic And Business, UIN Raden Fatah, Palembang, Indonesia \\ Corresponding author: rikalidyah_uin@radenfatah.ac.id
}

\begin{abstract}
The purpose of this research is to analyze and know how the influence of emotional marketing and lifestyle on customers decisions in choosing products of murabahah financing at PT Bank Syariah Mandiri KC Palembang Simpang Patal in partial and simultan. This research study is (explanatory research) using a quantitative approach. Source of data in this research use the primary data through questionnaire.The sample collection technique used is a method of purposive sampling, with the multiple regression analysis methods included in this research is 100 respondents who use murabahah financing at PT Bank Syariah Mandiri KC Palembang Simpang Patal. In this research data analysis techniques used SPSS 17.0 version. The research variables consist of the independent variable: 1.emotional marketing 2.lifestyle and the independent variable used the customers. The result show the research indicated that the emotional marketing and lifestyle significantly influence on customers decisions in choosing of the murabahah financing at PT Bank Syariah Mandiri KC Palembang Simpang patal
\end{abstract}

Keywords: Emotional Marketing, Lifestyle and Customers Decisions

\section{Introduction}

Indonesia is the country with the most muslim population in the world, that it becomes a great potential for marketing the product of syariah banking which increasing people's needs for syariah banking to spur the growth of syariah banks in Indonesia. The development of services especially in areas syariah banking must be able to offer a product to customers to seize the attention of the potential creditur with products based on their needs and desire of customers politically charged raid aimed at marketing to create positive perception of what the consumer is an important factor for the success of a products because ultimately judge the success of a product is consumers, so it is important for the bank to create emotional marketing. Because the marketing is not only about transaction in the market but also to seize their customers through products or services .

Domination of murabahah financing show that the financing had a lot of advantages for syariah banks .First certainty buyers that a bank not will buy goods except there are the buyer. Secondly, certainty profit will be a goods and murabahah financing easier applied at the moment . In addition the high risk of this murabahah financing, tend to have risk less than the other products and it can be secured for shareholder

Murabahah financing is one of the financing to the principle of the bargain which people try to the portion use in the of murabahah financing now greater than the total financing of syariah banks in Indonesia about $60 \%$.In 2017 the shariah bank financing be channelled to the community dominated by murabahah financing at 54,03\% increased 13,96\% Rp 17,03 trillion or of the total funding channeled 325,69 triliun. And it continue to rise until Rp154.51 trillion, with a total distribution of financing reached Rp 320,67 trillion in the june 2019 period . The increase was triggered by the increasing number of customers who use murabahah financing in syariah banks .

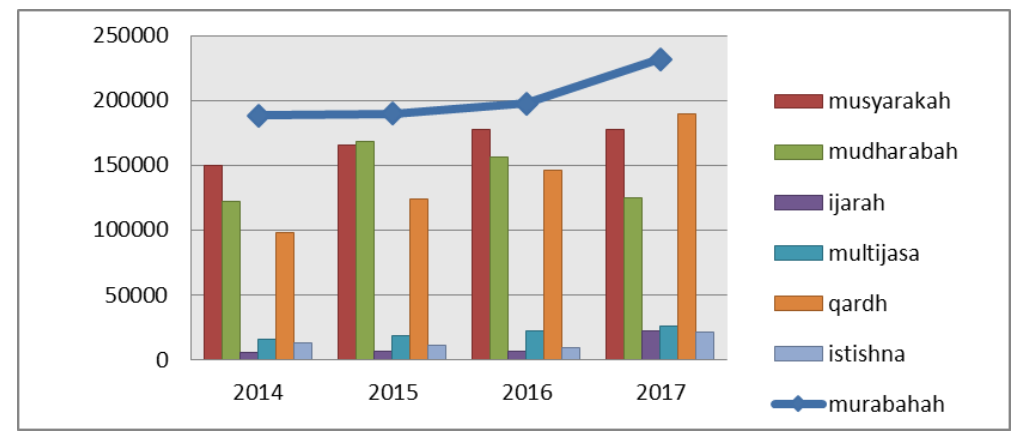

Source: Syariah Banking Statistics (data processed)

Figure 1. A funding of syariah banking ( in millions of rupiahs ) December of 2014-2017 
Some of the test which has been done on influence of the emotional marketing products to customers in line with research of murabahah funding by Sidatubar Octaria Cindy, Suharyono , Andriani Kusumawati ( 2016 ) emotional marketing shows that do not have significant influence of the decision of customers in choosing products . This contravenes the research conducted by Susilo and Hatan Se ( 2015 ) that showed that emotional marketing has influence significantly to purchase intension to customers in choosing products and research about the influence of lifestyle of the decision of customers in choosing murabahah financing products in line with research conducted by Natawijaya, D Sunarti, Edriana Pangestuti ( 2018 )that her research shows that lifestyle having influence a significant impact on decision customers in choosing products. This is contrast with research conducted by Veny Risky Amelia Aziz ( 2015 ) that showed that lifestyle have negative impact a significant impact on decision the purchase of customers in choosing a product.

\section{Literature Review \\ The Theory of Decision-making}

According to Suharnan (2005) decision making is the process of determining or choose among various possible uncertainly situation. Making decision occurring in future circumstances make estimation on the frequencies judgment and choose one of two options or more. This theory about how to bring a judge related consumers from bidding by stimulating someone to be for what they have felt and emotion in a product and also have worth or merit more than other products and eventually buy it or even the purchase.

\section{Emotional Marketing and Lifestyle Relationship With The Customers Decisions}

Robinnete et al in 2001 define emotional marketing as business company did to create a sustained in customers, so that they feel significant and consideration. Khuoang and Tram (2015) explained that basically the principle of happiness consumers arises from emotion and emotions that this is the important thing to investigated and managed well, so consumers find the good and connected to the product offered. Attitude who should be taken by a consumers in decision-making from the offers related by stimulating someone to be for what they felt in a product have emotion in it and it has value or benefits more than to the product and finally created more intensity the other who will increase in buy or even the purchase. According to Kotler and Keller ( 2005 ) lifestyle had "personality" who interact with them. According to Mowen and Minor Lifestyle ( 2002 ) showing how people live, how they spend the money, and how we allocate while they grow because they need and lifestyle, demands, and strengthening by which a conduct are repeated when behaviour took satisfaction or pleasure and there is no law where a accompanying lifestyle can affect the decision and will affect or even changing life style the person.

\section{Research Method}

In this research used the explanation research quantitative and use of the survey (questionnaire). The Population in this research is respondent of murabahah financing customers at PT. Bank Syariah Mandiri KC Palembang Simpang Patal. For measuring the perception of respondents distributed use likert scales. Technique used by purposive sampling. The sample in this research all indicators that have implemented all the validity and reliability, or where the valid and reliable, with the multiple regression analysis method. Regression of analysis using formulas show samples to be taken , a confidence with level of $95 \%$ used is in full estimation of 0,5\% 10 and the margin of error.The study sample is 100 respondents. To determine the impact of the decision emotional marketing and lifestyle products to customers murabahah financing at. PT. Bank Syariah Mandiri KC Palembang Simpang Patal Technical data analysis using spss 17.0 version.

\section{Result and Discusssion}

Based on results, information obtained that of as many as 100 respondents which 86 men and 14 of women respondents. And some of large respondents was 30-39 years and work as private employees with university is 56 respondents .

Table 1. Test results on the assumption classic

\begin{tabular}{|c|c|c|c|c|c|}
\hline Normality test (Kolmogorov-Smirnov) & Asymp.sig & 0,379 & $>$ & 0.05 & \\
\hline \multirow[t]{2}{*}{ Multicollinearity test (Tolerencedan VIF) } & $\mathrm{X} 1$ & Tolerence & 0,377 & VIF & 2.649 \\
\hline & $\mathrm{X} 2$ & Tolerence & 0,377 & VIF & 2.649 \\
\hline \multirow[t]{2}{*}{ Heteroscedasticity test (Ujiglejser) } & $\mathrm{X} 1$ & & & & 0,558 \\
\hline & $\mathrm{X} 2$ & & & & 0,587 \\
\hline Autocorrelation test (Durbin-watson) & Nilai Durbin-watson & $\mathrm{d}_{\mathrm{u}}(1.74)$ & 2.005 & & $\begin{array}{c}4-d_{u} \\
(2.26)\end{array}$ \\
\hline \multirow[t]{2}{*}{ Linearity Test (Test for linearity) } & Equation 1 & 0,000 & $<$ & & 0.05 \\
\hline & Equation 2 & 0,000 & $<$ & & 0,05 \\
\hline
\end{tabular}

Source: data output spss , 2020 data processed. 
Based on the table 1 shows that data with distributed normally with has value asymp.signifikan as much as $0,379>0.05$. While in multicollinearity test can be seen that all the value of tolerance and vif $<10$ thus data multicollinearity does not happen. Based on the classic assumption by using glejser shows that the data does not happen heteroscedasticity because each of variable on top of the probability of having a value greater than the value of alpha ( sig.0.05 ). Based on the autocorrelation shows that is not have a problem of autocorrelation regression at this model because the durbin-watson determined obtained are a lower borders of the upper limit and requirements. Based on the test for linearity, linearity with it can be concluded that all the variables independent having a linear dependent variable. Obtained significant where the $0,000 \&$ it; 0.005 .

Table 2. The results of the analysis linear regression

\begin{tabular}{llcc}
\hline & & \multicolumn{2}{c}{ Unstandardized Coefficients } \\
\cline { 2 - 4 } \multicolumn{2}{c}{ Model } & B & Std. Error \\
\hline 1 & (Constant) & .937 & .303 \\
& X.1 & .363 & .117 \\
& X.2 & .430 & .100 \\
\hline
\end{tabular}

Source : Of the output spss 2020

Linear regression on this research is multiple can be seen that emotional marketing (X1) and lifestyle ( $\mathrm{X} 2$ ) to customers decision in the equation formulated as follows:

$$
\mathrm{Y}=\mathbf{0 , 9 3 7}+\mathbf{0 , 3 6 3}(\mathrm{X} 1)+\mathbf{0 , 4 3 0}(\mathrm{X} 2)
$$

Table 3. Test results on a hypothesis

\begin{tabular}{lcrl}
\hline F test & & 65,145 & Sig.0.000 \\
\hline T test & $\mathrm{X} 1$ & 3.101 & Sig.0.003 \\
\hline \multicolumn{1}{c}{ X2 } & 4.303 & Sig.0.000 \\
\hline Coefficient of determination R2 & R square & 0,573 & \\
\hline \multicolumn{2}{l}{ Source: , spss output, (2020 ) data processed }
\end{tabular}

Table 3 showed that the Fcount of $65,145>3,09$; and the significantly by $0,000<0,05$; marketing emotional and lifestyle that simultaneously or together significant in customers choosing to submit products murabahah financing at PT. Bank Syariah Mandiri KC Palembang Simpang Patal. From the data it can be seen that the emotional marketing variable tcount of 3,101 $>1,984$; and the significance of $0,003<0,05$ That emotional marketing in partial significant in customers choosing to submit products murabahah financing. This supposed identify that if taken by a judge stimulate consumers from someone to be for what they have felt in a product that have emotion in it and benefits of value more than to the others product and may ultimately increase intencity to buy or even the purchase. From the data can be seen that the values of variable tcount lifestyle 4,303 $>1.984$ and value of significance $0,000<0,05$ it means that lifestyle have an partial significant impact on the customers decision in choosing products murabahah financing . This shows that a consumer behavior will be repeated if the character took satisfaction or pleasure and there is no law accompanying where a lifestyle can influence a decision in itself which then influence or even turned the lifestyle. From the table above it can be seen that the $r$ square of 0,573 which means that percentage dependent variable proportion of $57,343,7 \% \%$ while other described by other variables that are not included in this research.

\section{Conclusion}

Based on the research, the conclusion can be drawn as follows: 1 .this research give a significantly in partial influence on the variables of emotional marketing of the customers decision .This identify that the more high levels of feeling and confidence the customers to a product has emotion value in it and it has value or more benefit compared to other products , to give the effect of to augment the intensity of the purchase of consumers, to finally turn consumers loyal of the PT. Bank Syariah Mandiri KC Palembang Simpang Patal .2 ) and in this variable show the partial significant on variable lifestyle in customers decision. This indicates that the needs and demands of any different lifestyle customers, which needs and demands of the high level of someone lifestyle they can influences the high level of a decision that will customers taken, the needs for the high they can a product needs lifestyle, so it could improve the intensity of the customers and will affect or even changing lifestyle of the customers.

\section{References}

Agus Tri Basukidan Nano Prawoto,Analisis Refresi dan Penelitian Ekonomi \& Bisnis, (Jakarta: PT.Raja Grafindo Persada,2016).hlm.104 
Albert Kurniawan. Metode Riset untuk Ekonomi dan bisnis.hlm.158

Duwi Priyatno, Buku saku SPSS, Analisis Statistik data, Lebih cepat, Efisien, dan akurat ( Jakarta: Mediakom 2011),hlm,11.

Fandy Tjiptono,"Manajemen Jasa”,(Yogyakarta :Andi Offset,2015),hlm.58

Getut Pramesti, Statistika Lengkap Secara Teori dan Aplikasi SPSS 23, (Jakarta: PT.Elex Media Komputindo,2016),hlm.69.

Imam Ghozali, aplikasi analisis multivariate dengan program IBM SPSS 23, (semarang: BPFE Universitas Ponegoro,2016.),hlm 96.

Imam Ghozali,Op.Cit,Hal.160

IrhamFahmi, Perilaku Konsumen Teori dan Aplikasi, (Bandung: ALFABETA,2016).

Jurnal

Edi Santoso,Riawan,Strateg iPemasaran Produk Bank Pembiayaan Rakyat dari total pembiayaan Syariah(BPRS),3(03),2017,hal157-166.

Ela patriana, Nurismalatri,Analisis Faktor Penentu Keputusan konsumen Muslim dalam memilih jasa Perbankan :Bank Syariah Vs Bank konvensional ,jurnal lembaga keuangan dan perbankan, Volume 3, Nomor 1, (Januari-Juni 2018).

Evi Asmayadi,Srihartini,The Impact of Service Quality and Product quality Toward Customer Loyality Through Emotional and Functional values in Traditional Market In Pontianak, Indonesia, European Journal Of Bussiness and Management, Volume 7, Nomor 5, (2015).

Geraldo Gunawan, yusriabdilah, (dkk),Pengaruh experiental Marketing dan emotional marketing Terhadap Brand loyalty (Survei pada Konsumen Smartphone Samsung di Indonesia dan malaysia),Jurnal fakultas Ilmu administrasi Univeristas Brawijaya,2018.

Moh.Ansyar, Analisis pembiayaan Murabahah pada PT Bank SyariahMandiri KCP PaluTadaluko, e-journal katalogis, Volume 3,Nomor 10,(Oktober 2015),hlm.96-104.

Muhamad syaefulahdanEndang."Analisis Pembiayaan Murabahah (Peran perempuan Selaku pengambil kebijakan pembiayaan dan nasabah pada Pt Bank MuamalatIndonesia,TbkCabang Pontianak)". Jurnal Studi Gender danAnak

Reason James.1990.Human Error Ashgate. ISBN-1.84014-104-2. 